Pediat. Res. 11: 325 (1977)

\title{
Editorial: The Expanding Horizons of Pediatric Research
}

The issues facing pediatric research today demand an extension of traditional approaches to current questions. This will require a new kind of dialogue and a wider group of participants.

Pediatric Research, in some quarters, has been associated with a narrow spectrum of research interests. It is the intent of the Editorial Board, however, that the content of the Journal should be responsive to developments in pediatrics in whatever field and in whatever part of the world innovative ideas are generated.

Shown in the accompanying table is a distribution of papers accepted for publication in Pediatric Research in 1975 and 1976.

As can be seen from this table, the largest number of articles published in 1975 were in the areas of genetics, metabolism, hematology, pulmonology, and endocrinology. In 1976, although the largest number of articles still continued to come from the areas of metabolism and pulmonology, a significant increase was noted in the immunology and cardiology categories. At first glance the reader may perceive this as a matter of editorial policy, but this is not so. The Journal can only publish those articles submitted to it. It is the desire of the Editors that with further stimulation of the interest of the sponsoring societies manuscripts will be submitted from areas of

Copyright (1) 1977 International Pediatric Research Foundation, Inc.

\begin{tabular}{|c|c|c|c|c|c|}
\hline Field of study & 1975 & 1976 & Field of study & 1975 & 1976 \\
\hline Behavioral sciences & 1 & 3 & Immunology & 3 & 12 \\
\hline Cardiology & 2 & 9 & Infectious diseases & 5 & 3 \\
\hline $\begin{array}{l}\text { Developmental biol- } \\
\text { ogy }\end{array}$ & 9 & 8 & Metabolism & 32 & 57 \\
\hline $\begin{array}{l}\text { Developmental phar- } \\
\text { macology }\end{array}$ & 4 & 2 & Morphogenesis & 0 & 1 \\
\hline Endocrinology & 12 & 2 & Neonatology & 3 & 4 \\
\hline Epidemiology & 2 & $\mathbf{0}$ & Nephrology & 5 & 4 \\
\hline $\begin{array}{l}\text { Gastroenterology } \\
\text { and nutrition }\end{array}$ & 7 & 9 & Neurology & 3 & 2 \\
\hline Genetics & 20 & 6 & Oncology & 0 & 0 \\
\hline Hematology & 10 & 9 & Pulmonology & 12 & 10 \\
\hline
\end{tabular}

research which are underrepresented, and it is our hope that when this list is next examined it will reflect the broader interests and research needs of the multiple disciplines which comprise pediatric research.

THE EDITORS

Printed in U.S.A. 